\title{
PENERAPAN APLIKASI MY JICT DALAM MENINGKATKAN USAHA TERMINAL PETI KEMAS DI ERA 4.0
}

\author{
Ratna Kurnia Dewi ${ }^{1^{*}}$, Fakhrurrozi ${ }^{2}$ \\ ${ }^{1}$ Program studi Transportasi Laut, Politeknik Bumi Akpelni \\ Jl. Pawayatan Luhur II/17, Bendan Dhuwur, Semarang. \\ ${ }^{2}$ Program studi Nautika, Politeknik Bumi Akpelni \\ Jl Pawayatan Luhur II, Bendan Dhuwur, Semarang. \\ "Email: ratna.kurnia.dewi@ akpelni.ac.id
}

\begin{abstract}
Abstrak
Kajian tentang penerapan aplikasi My JICT dalam meningkatkan usaha terminal peti kemas di era 4.0. merupakan suatu bentuk peningkatan pelayanan di JICT dalam penanganan muatan petikemas akibat lamanya proses pengurusan dokumen custom clearance, serta kendala-kendala yang lain. Penelitian didasarkan pada penelitian kualitatif ini dilakukan di PT JICT dan beberapa perusahaan pengguna jasa dari PT JICT., dengan mendasarkan hasil penelitian dari wawancara sebagai data primer dan dari literasi dan kepustakaan sebagai data sekunder. Ruang lingkup permasalahan membahas mengenai : 1) Bagaimana penerapan aplikasi My JICT, serta kendala yang dihadapi oleh Jakarta International Container Terminal (JICT)?, 2) Bagaimana persepsi customers mengenai penggunaan aplikasi My JICT, dalam proses penanganan muatan kontainer oleh JICT di era 4.0?, dan 3) Bagaimana persepsi karyawan JICT mengenai penggunaan aplikasi My JICT dalam meningkatkan Usaha Terminal Petikemas?. Ada tiga klaster dokumen barang dan kapal dalam aplikasi My JICT mengintegrasikan siklus layanan utama, yaitu sistem E-billing, sistem Autogate, dan sistem elektronik Delivery Order (DO) online untuk integrasi dokumen kapal. Keuntungan dalam penggunaan aplikasi My JICT yaitu memudahkan proses pembayaran atas jasa kepelabuhanan khususnya untuk pemuatan kontainer, dapat mengatur cash flow sesuai dengan kebutuhan penanganan muatan kontainer, dari beberapa layanan terminal di dalam satu aplikasi dengan sederhana yang diintegrasikan secara baik dan tepat. Dengan diterapkannya sistem elektronik yang cepat dan efisien di pelabuhan, telah mendorong dan meningkatkan adanya peningkatkan penetrasi percepatan layanan antar lembaga, dan pelayanan elektronik pelabuhan 24 jam menjadi langkah awal dalam pelaksanaan pengoperasian pelabuhan yang modern dan handal di Indonesia.
\end{abstract}

Kata kunci: Aplikasi, Kontainer, Pelabuhan, Digitalisasi

\section{PENDAHULUAN}

Transportasi melalui laut dalam mendukung upaya pembangunan ekonomi negara, memegang peranan penting dalam sistem perdagangan global di era 4.0. melalui transportasi laut, hampir semua jenis barang dan jasa pelayanan pengiriman pengiriman barang di dunia ini dapat dipindahkan dari satu tempat ke tempat secara cepat. Indonesia sebagai negara kepulauan, masih memerlukan adanya pengembangan dan penambahan infrastruktur dalam memperlancar kegiatan transportasi melalui laut. Peran pelabuhan penting untuk mendukung pengembangan industri dan perekonomian nasional. Namun peran ini belum sepenuhnya terjawab, masih banyak kendala birokrasi yang mengakibatkan barang atau muatan menjadi lama tertahan di pelabuhan dan belum dapat diselesaikan atau dikeluarkan karena masalah administrasi yang belum selesai. Segala bentuk pelayanan yang belum menggunakan teknologi mutakhir, khususnya adalah teknologi digitalisasi menggunakan sistem yang terintegrasi, juga menjadi penghambat dalam memberikan suatu percepatan dalam pelayanan.

Untuk itu pemerintah terus mengembangkan industri di berbagai sektor dalam program poros maritim nasional Indonesia. Pemerintah telah berupaya menyediakan sarana dan prasarana, dan kelengkapan fasilitas pelabuhan yang lengkap serta kualitas Sumber Daya Manusia (SDM), pengelola dan yang memberikan pelayanan di pelabuhan guna meningkatkan daya saing pelabuhan di Indonesia. Industri transportasi, 
logistik, pelayaran dan pelabuhan tradisional, diharapkan dapat berubah ke arah otomatisasi dan digitalisasi, sehingga mampu bersaing di era 4.0 ini. Segala bentuk pelayanan di era 4.0, lebih memfokuskan dalam bentuk pelayanan dengan menggunakan layanan otomatis dan digital. Kegiatan di sektor transportasi dan logistik, serta kepelabuhanan, di era 4.0 ini senantiasa dituntut untuk terus ditingkatkan dan diharapkan dapat mulai beralih ke sistem otomatisasi. Saat ini sistem teknologi Artificial Intelligence (AI) dan Internet of Things (IoT) menjadi suatu sistem yang diharapkan dapat memenuhi kebutuhan pelayanan tersebut.

Melalui digitalisasi pelabuhan, pelayanan dalam mendapatkan akses informasi terkait pergerakan kegiatan, dan biaya-biaya kapal setiap saat secara cepat dan akurat dapat secara langsung diperoleh. Efisiensi biaya, percepatan waktu pelayanan kapal di pelabuhan, mudah dan transparan, menjadi lebih baik dan terus terdorong melalui layanan digital ini. Sebagai contoh adalah bentuk layanan pemanduan dan penundaan kapal, layanan jadwal dan penyandaran kapal. Di pelabuhan Jakarta yang sudah menggunakan sistem digital, hal ini menjadikan semua perusahaan pelayaran dapat memantau kegiatan tersebut melalui semuanya.

Pelayanan otomatisasi dan digitalisasi ini juga telah berkembang pada layanan kegiatan ekspor dan impor menggunakan kontainer. Perpindahan barang dalam proses ekspor dan impor ini juga perlu dikendalikan, disinilah terminal petikemas memegang peranan penting untuk melakukan kegiatan ekspor dan impor dan tempat penimbunan sementara. Layanan ini adalah layanan dalam proses pengumpulan petikemas dari para pengirim barang atau dari pelabuhan-pelabuhan lain, untuk selanjutnya diangkut ke tempat tujuan atau ke tempat penumpukan utama di pelabuhan Jakarta yaitu di Terminal Petikemas Jakarta International Container Terminal (JICT).

Terminal Petikemas JICT menjadi terminal peti kemas pertama di Indonesia, yang mendapat sertifikasi (International Ship and Port Security) ISPS Code di Indonesia, menjadikan JICT dipercaya oleh dunia pelayaran internasional sebagai tempat bersandar kapalkapal dari luar negeri karena fasilitas keamanan yang lengkap, sehingga mampu menjamin keamanan dan keselamatan kapal-kapal yang sandar. Namun dalam operasional arus pelayanan keluar masuk petikemas sering terkendala dalam pelayanan dokumen, custom clearance, waktu transaksi yang cukup lama di pintu masuk pelabuhan dan waktu tunggu bagi angkutan truk di area parkir serta masih adanya pungli dalam setiap pelayanan jasa pengurusan petikemas.

Manajemen Jakarta International Container Terminal (JICT) di Pelabuhan Tanjung Priok memperkenalkan sistem jaringan (daring), dalam memberikan pelayanan yang nantinya akan menjadi model bagi pelabuhanpelabuhan lainnya di Indonesia. Sistem itu dikenal sebagai aplikasi My JICT, yang telah diintegrasikan dengan baik pada sistem Inaportnet. Sistem inaportnet ini memberikan suatu layanan utama yang dibagi dalam tiga klaster dokumen barang dan kapal, yaitu sistem E-billing, secara terintegrasi. Konektivitas pelayanan online ini meliputi pelayanan dalam pembayaran dokumen ekspor impor, sistem Autogate untuk pelayanan truk ekspor impor, sistem elektronik delivery order (DO) online, sehingga layanan dokumen kapal dapat terintegrasi. Dalam menjalankan dan mengoperasikan layanan ini, dibutuhkan SDM yang memiliki kompetensi dan kemampuan keterampilan di bidang otomatisasi dan digitalisasi. Demikian juga dalam memberikan peningkatan dan percepatan pelayanan kepada Customer, program inaportnet dan aplikasi $M y$ JICT ini terus diupgrade dan dikembangkan. Pelayanan yang diberikan ini diharapkan benarbenar dapat memberikan suatu kemudahan dan akan menjadi pelayanan yang bersih dan transparan kepada para customer dan pengguna jasa dari Terminal Petikemas JICT di Jakarta. Penelitian ini bertujuan untuk mengetahui dan menganalisis mengenai penerapan aplikasi $M y$ $J I C T$, serta kendala yang dihadapi oleh Jakarta International Container Terminal (JICT), mengetahui dan menganalisis mengenai persepsi customers mengenai penggunaan aplikasi $M y$ $J I C T$, dalam proses penanganan muatan kontainer oleh JICT di era 4.0, serta mengetahui dan menganalisis mengenai persepsi karyawan JICT mengenai penggunaan aplikasi My JICT dalam meningkatkan usaha Terminal Petikemas.

\section{LANDASAN TEORI}

Penerapan adalah proses, cara, perbuatan menerapkan, (Kamus Besar Bahasa Indonesia/ $\mathrm{KBBI}$ ). Sedangkan pengertian penerapan menurut J.S Badudu dan Sutan Mohammad Zain dalam Peter Salim dan Yenny Salim (2002) 
adalah mempraktekkan, memasangkan. Riant Nugroho (2003), yang dimaksud penerapan pada prinsipnya adalah segala sesuatu yang dapat dilakukan untuk mencapai tujuan yang diinginkan.

Adapun unsur-unsur penerapan menurut Peter Salim (2002), melitputi:

1. Tersedianya program yang dilakukan.

2. Siapa sasaran yang diharapkan akan menerima manfaat dari program tersebut.

3. Pelaksanaan. Dilaksanakan baik oleh organisasi atau perorangan yang bertanggung jawab.

Menurut Marimin (2004) aplikasi merupakan program dalam sistem komputer yang secara langsung dapat melakukan prosesproses pengolahan data secara cepat yang diinginkan oleh pengguna. Didalam aplikasi terdapat kumpulan file-file tertentu yang berisi kode program yang dapat menghubungkan antara pengguna atau pemogram dan perangkat keras komputer yang sering disebut sebagai device driver), untuk melakukan proses perhitungan, dan berinteraksi dengan aplikasi yang lebih mendasar lainnya. Aplikasi menurut tingkatannya dapat dikategorikan sebagai tingkatan program aplikasi (application program seperti program Microsoft Office), tingkatan sistem operasi (operating system yaitu program Microsoft Windows), dan tingkatan bahasa pemrograman (PHP).

Suyono (2007) berpendapat bahwa petikemas adalah satu kemasan yang dirancang secara khusus dengan ukuran tertentu, dapat dipakai berulang kali, dipergunakan untuk menyimpan dan sekaligus mengangkut muatan yang ada di dalamnya. Kontainer atau yang dikenal dengan petikemas adalah sebuah peti yang terbuat dari logam, yang memuat barangbarang yang lazim disebut sebagai muatan umum (general cargo), yang akan dikirimkan melalui laut.

Terminal petikemas adalah terminal di mana dilakukan pengumpulan petikemas dari hinterland ataupun pelabuhan lainnya untuk selanjutnya diangkut ke tempat tujuan ataupun terminal petikemas (Unit Terminal Container) disingkat secara umum "UTC" yang lebih besar lagi. Berdasarkan Pasal 1 huruf d Keputusan Direksi Pelabuhan Indonesia II Nomor HK.56/2/25/P.II-2002, yang dimaksud terminal petikemas adalah terminal yang dilengkapi sekurang-kurangnya dengan fasilitas berupa tambatan, dermaga, lapangan penumpukan (container yard), serta peralatan yang layak untuk melayani kegiatan bongkar muat petikemas.

Pengertian industri 4.0 adalah tren di dunia industri yang menggabungkan teknologi otomatisasi dengan teknologi cyber. Pada industri 4.0, teknologi manufaktur sudah masuk pada tren otomatisasi dan pertukaran data. Hal tersebut mencakup sistem cyber-fisik, internet of things (IoT), komputasi awan, dan komputasi kognitif. Tren ini telah mengubah banyak bidang kehidupan manusia, termasuk ekonomi, dunia kerja, bahkan gaya hidup manusia itu sendiri. Singkatnya, revolusi industri 4.0 menanamkan teknologi cerdas yang dapat terhubung dengan berbagai bidang kehidupan manusia.

\section{METODE}

Penelitian kualitatif dengan metode ilmiah digunakan penulis dalam menyelesaikan penulisan ini, sengan Spesifikasi penelitian yang bersifat deskriptif analitis. Sumber data yang diperlukan guna memperoleh data yang objektif. Untuk memperoleh data yang akurat dan faktual, maka diperlukan data primer dan data sekunder. Sumber data yang peneliti peroleh dari data primer yaitu wawancara dan data sekunder dari literasi dan kepustakaan.

Data yang telah terkumpul, disajikan dalam bentuk penjelasan berupa kalimat yang mudah dipahami. Data diproses secara editing setelah diperiksa, diteliti, untuk menjamin bahwa data dapat dipertanggungjawabkan sesuai dengan kenyataan. Analisis data digunakan adalah analisis data kualitatif.

\section{HASIL DAN PEMBAHASAN}

\section{Penerapan Aplikasi My JICT, serta Kendala yang Dihadapi oleh Jakarta International Container Terminal (JICT).}

Persaingan dalam dunia industri pelayaran, yang sering dikenal dengan persaingan era Revolusi Industri 4.0, semakin menjadi sorotan. Upaya-upaya dalam memberikan suatu bentuk percepatan dalam pelayanan menjadi penentu dari keberhasilan peningkatan industri nasional, khususnya dalam jasa pelayanan industri pelayaran. Pelayanan dalam penanganan muatan kontainer juga terus di tingkatkan, guna menunjang keberhasilan dalam upaya optimalisasi pelayanan ekspor dan impor. Kepastian waktu atau masa inap barang atau dikenal dengan dwelling time di pelabuhan serta mahalnya komponen biaya logistik menjadi 
salah satu kendala dan dinilai telah menyebabkan daya saing logistik Indonesia tertinggal dibanding Vietnam dan Malaysia. Kehadiran revolusi industri 4.0 ditandai dengan otomatisasi dan digitalisasi dan hampir semua industri mengharapkan adanya otomatisasi guna mendorong bisnisnya, termasuk industri di pelabuhan. Pemerintah melalui Kementrian Perhubungan terus berusaha mewujudkan itu semua dengan menjadikan pelabuhan di Indonesia menjadi smart port dan smart supply chain. Program ini dimulai dengan adanya perubahan pelayanan secara digitalisasi. Adanya transhub challenge, dapat untuk mendorong start-up digitalisasi di bidang transportasi menjadi lebih cepat dan lebih maju sampai dengan upaya mengembangkan sistem inaportnet versi 2.0.

Teknologi informasi yang diterapkan oleh Pelabuhan Indonesia, menjadi salah satu grand strategy dan kebijakan umum di sektor transportasi laut. Teknologi ini telah mendasari seluruh kegiatan yang dilaksanakan oleh Pemerintah, termasuk dalam bidang kepelabuhanan. Dalam konsep sebagai pelabuhan modern, sebuah pelabuhan tidak hanya dijadikan sebagai transportation center saja, tetapi juga menjadi sebuah logistic and service center. Dengan demikian maka akan ada banyak transaksi ekonomi dan administrasi yang dilakukan. Disinilah teknologi informasi berperan untuk membuat proses transaksi ekonomi dan administrasi bisa dilakukan lebih cepat, murah, dan transparan serta dapat dipertanggungjawabkan. Penerapan digitalisasi di pelabuhan nasional saat ini adalah untuk mewujudkan 4th generation port, di mana seluruh proses di pelabuhan bisa saling terintegrasi, diakses, dan diawasi dalam satu sistem yang terpadu melalui sistem inaportnet. Pemerintah Indonesia telah menerapkan sistem inaportnet di 16 pelabuhan strategis dan digunakan secara harian, untuk mengelola layanan pelabuhan termasuk dokumen-dokumen mulai dari kedatangan dan keberangkatan kapal, proses kegiatan di pelabuhan seperti bongkar muat, sampai dengan pemantauan proses keluar masuk barang.

Tidak hanya pada sistemnya saja yang diperbaiki, Pelabuhan Indonesia II (Pelindo II) juga telah mengoptimalkan pelayanan penanganan muatan petikemas untuk semua pelayanan yang ada di pelabuhan Jakarta International Container Terminal (JICT 1 dan
JICT 2) dengan membuat suatu aplikasi yaitu $M y$ JICT. JICT adalah perusahaan jasa bongkar muat peti kemas terluas dan besar serta teramai dalam pelayanan di Indonesia. JICT beroperasi di Pelabuhan Tanjung Priok. Dedikasi tenaga kerja yang berpengalaman dan penerapan teknologi mutakhir yang berbasis pada sistem digitalisasi, menjadikan modal dasar dalam memberikan layanan terbaik kepada customer.

Pengembangan ini tidak lain adalah untuk memberikan pelayanan kepada pengguna jasa pelabuhan sesuai dengan standar pelayanan yang ditetapkan. oleh Pemerintah berdasarkan ketentuan yang ada di dalam Pasal 94 huruf b dari UU No. 17 Tahun 2008 tentang Pelayaran dan Pasal 73 huruf b PP No. 61 Tahun 2009 tentang Kepelabuhanan. JICT juga telah memenuhi semua standar mutu dalam pelayanan dan juga fasilitas tempat penumpukan petikemas berdasarkan Pasal 70 ayat (1) huruf b dari PP No. 61 Tahun 2009 tentang Kepelabuhanan.

\section{Aplikasi My JICT}

Jakarta International Container Terminal (JICT) yang merupakan usaha jasa di bidang pelayanan kontainer di Pelabuhan Tanjung Priok Jakarta, yang merupakan bagian dari Pelabuhan Indonesia II (Pelindo II), telah beroperasi sejak April 1999, dan bertujuan untuk memberikan layanan yang sangat baik melalui dedikasi tenaga kerja yang berpengalaman dan penerapan teknologi mutakhir terbaru. Disamping sebagai pelopor Terminal yang steril, dengan pelayanan keselematan, keamanan dan kebersihan di setiap lini lingkungannya, JICT menyediakan layanan berkualitas ke lebih dari 20 jalur pelayaran dengan rute langsung ke lebih dari 25 negara. JICT selalu berkomitmen untuk menyediakan layanan yang cepat, efisien, dan andal selama 24 jam sehari dalam 7 hari, sepanjang tahun. Untuk itu maka JICT memberikan suatu aplikasi pelayanan berupa aplikasi My JICT.

Aplikasi My JICT oleh manajemen Jakarta International Container Terminal (JICT) mulai diperkenalkan kepada publik pada 4 Maret 2018, di Pelabuhan Tanjung Priok, sebagai sistem pelayanan dalam jaringan (daring), yang nantinya akan menjadi model bagi pelabuhan-pelabuhan di Indonesia. Dengan keberadaan sistem online ini maka penyedia jasa perantara yang biasa mengurus kapal akan tereliminasi dan para importir dapat mengurus berkasnya secara langsung dari kantornya masing-masing. 
Sistem pelayanan di pelabuhan selama 24 jam sehari dan 7 hari dalam sepekan atau 24/7 secara terintegrasi, sebagaimana yang diharapkan oleh Kementrian Perhubungan, siap dijalankan oleh Aplikasi My JICT yang dibuat oleh Jakarta International Container Terminal (JICT). Integrasi dari sistem My JICT ini diharapkan dapat meningkatkan penetrasi percepatan layanan antar lembaga, dengan mendorong diterapkannya sistem elektronik yang cepat dan efisien di pelabuhan. My JICT yang telah dikembangkan akan menjadi bagian dan langkah awal, dalam pelaksanaan pelayanan secara elektronik di pelabuhan dalam waktu 24/7 yang andal di Indonesia dalam beberapa tahun ke depan. Sistem ini akan mengintegrasikan siklus layanan utama yang dibagi dalam tiga klaster dokumen barang dan kapal, yaitu :

1. sistem pelayanan pembayaran dokumen ekspor impor dengan menggunakan sistem $E$ billing untuk,

2. untuk pelayanan truk ekspor impor dengan sistem Autogater, dan

3. untuk integrasi dokumen kapal dengan sistem elektronik Delivery Order (DO) online.

Selain tiga layanan utama, aplikasi $M y$ JICT juga dapat melayani transaksi pelayanan petikemas kosong (empty container) dan beberapa transaksi dengan depo-depo petikemas. Semua bentuk dan pelayanan dalam penyelesaian dokumen ekspor impor, dilakukan secara terintegrasi, cepat dan efisien dengan basis real-time. Aplikasi My JICT dengan keseluruhan program yang telah terintegrasi, diharapkan akan memberikan kemudahan bagi para pengguna jasa pelayanan penanganan ekspor impor barang menggunakan petikemas. Dalam penerapannya, Aplikasi My JICT mampu meningkatkan operasional pelayanan yang lebih efektif dan secara otomatis dapat meningkatkan kapasitas penanganan tahunan terhadap pelayanan petikemas di terminal JICT menjadi 2,8 juta TEUs. Dan berdasarkan data bulan Mei 2021, arus petikemas di JICT tercatat 807,239 TEUs.

Aplikasi My JICT memberikan layanan kemudahan kepada para penggunanya yaitu :

1. GBOSS billing web interface (GBOSS);

2. Hold and Release Container for Customs Inspection (Custom $\mathrm{P} 2$ );

3. Export empty Container Reposition (Empty Repo);

4. Invoice Depo Lini 2 (Invoice PLP);

5. Kios dan TPS online;
6. Document Tracking System (DTS).

Untuk pelayanan dalam bentuk online service, yang disediakan oleh Aplikasi My JICT yaitu:

1. VGM Certificate,

2. Vessel Schedule,

3. Container Tracking,

4. My JICT,

5. Tarif, dan

6. Reprint EIR

Aplikasi My JICT saat ini digunakan oleh beberapa perusahaan pengangkut muatan kontainer terkemuka dengan kapasitas besar, seperti Orient Overseas Container Line (OOCL) yang merupakan sebuah perusahaan penyedia layanan logistik dan pengapalan petikemas asal Hong Kong, Ocean Network Express (ONE) yang merupakan perusahaan pengapalan peti kemas yang berkantor pusat di Tokyo, Jepang, yang dimiliki secara bersama-sama oleh Nippon Yusen Kaisha, Mitsui O.S.K. Lines, dan K-Line, Korea Marine Transport Containers (KMTC) perusahaan penyedia layanan kontainer asal Korea Selatan, China Ocean Shipping (Group) Company lebih dikenal sebagai COSCO atau COSCO Group adalah sebuah perusahaan penyedia jasa pengiriman dan logistik asal Tiongkok dan Compagnie Maritime d'Affrètement (CMA), Compagnie Générale Maritime (CGM) yang kemudian di kenal dengan CMA-CGM, yang merupakan perusahaan pengapalan dan transportasi petikemas asal Perancis, dan WAN HAI sebagai perusahaan penyedia layanan petikemas asal Taiwan.

Aplikasi My JICT milik Jakarta International Container Terminal telah mendapatkan pengakuan dan sertifikasi dari ISO 14001:2015, yang diberikan oleh Joint Accreditation Systems of Australia and New Zeeland (JAS-ANZ), Canberra, Australia, sekaligus juga ISO 45001:2018.

Berdasarkan data penelitian yang peneliti dapatkan dari hasil wawancara secara daring online dengan Maman Suhatman selaku Operational Manager OOCL, bahwa selama menggunakan jasa layanan aplikasi My JICT, secara sistem belum ada kendala yang yang selama ini dapat menghambat pelayanan. Hanya saja, karena sistem ini merupakan suatu layanan online, yang sangat berpengaruh adalah kondisi network atau layanan jaringan internet dari provider atau penyedia networking. Pernyataan ini juga dibenarkan oleh Waduge Sanjaya selaku Operational Manager CMA-CGM. 
Sebagaimana yang disampaikan oleh Budi Cahyono selaku Wakil Direktur Utama JICT, impelementasi atau penerapan aplikasi My JICT dalam sistemnya belum menemukan kendala dan masalah dalam melayani sistem pelayanan petikemas di pelabuhan untuk $24 / 7$ atau 24 jam dalam seminggu, di beberapa lini pelayanan utama internal. Namun, pernah ada kendala yang ditemukan, tetapi bukan pada sistem aplikasinya, yaitu pernah terjadi bahwa sistem pintu masuk otomatis JICT, yang sempat mengalami masalah sehingga menyebabkan antrian panjang bagi kendaraan barang yang akan masuk ke pelabuhan JICT tersebut. Pada saat itu kegiatan proses bongkar muat tetap berjalan secara normal. Kondisi ini langsung ditangani dan telah dilakukan perbaikan, sehingga sistem pintu otomatis tersebut telah dapat segera beroperasi normal hingga saat ini.

Budi Cahyono menambahkan bahwa JICT akan terus berupaya memberikan pelayananan terbaik kepada seluruh Customer yang telah memberikan kepercayaan dengan menyandarkan kapal kapal di JICT. Peningkatan layanan ini dibuktikan dengan kunjungan kapal perdana dari Ocean Network Express (ONE) untuk China Indonesia Malaysia 2 Service, yang secara rutin akan mendatangi JICT setiap minggunya, milik perusahaan Goldstar Line Shipping.

Untuk menghilangkan kendala yang mungkin terjadi, JICT tidak hanya berkomitmen dalam peningkatan pelayanan jasanya saja, namun juga berkomitmen penuh untuk meningkatkan standar tertinggi terkait kebijakan, keselamatan kerja, kesehatan dan lingkungan yang sehat untuk seluruh pemangku kepentingan. Untuk memberikan perlindungan di tempat kerja dari insiden atau kecelakaan bagi para pegawai, perusahaan sebaiknya selalu rajin untuk melakukan penyegaran untuk mengingatkan insan didalamnya mengenai pentingnya perhatian terhadap keselamatan kerja dengan memberikan pelatihan dan penyegaran tentang pentingnya keselamatan kerja. Hal ini bertujuan untuk menjadi panduan terhadap pentingnya keselamatan kerja. Safety bukan merupakan urusan pribadi, melainkan tanggung jawab bersama. Saling mendukung, mengingatkan rekan kerja dan terus mematuhi setiap protokol keselamatan dan kesehatan kerja merupakan langkah penting agar semua pihak selamat dalam bekerja.

\section{Persepsi Customers Mengenai Penggunaan Aplikasi My JICT, dalam Proses Penanganan Muatan Kontainer oleh JICT di Era 4.0.}

Perubahan dalam pelayanan secara fisik ke pelayanan sistem online di Era 4.0 ini tentunya membawa banyak perubahan besar dalam suatu tatanan birokrasi pelayanan jasa. Dengan meluncurkan suatu produk pelayanan jasa dibidang penanganan muatan kontainer, yang terintegrasi melalui suatu sistem aplikasi My JICT, telah menunjukkan bahwa JICT tidak main-main dalam mendukung program pemerintah dalam mengurangi masa tunggu ataupun dwelling time.

Pelabuhan Tanjung Priok, sebagai pelabuhan dengan kegiatan impor yang tinggi, hingga saat ini masih saja terkendala dengan dwelling time. Tentunya ini menjadi sorotan utama yang selalu dibahas dan dikaji dalam setiap momen wawancara tentang kebijakan ekspor impor. Terlebih lagi setelah Presiden RI Joko Widodo pada Tahun 2014 berkunjung ke Tanjung Priok dan mengungkapkan bahwa dwelling time masih berlangsung sekitar 7 hari pada saat itu (Kantor Staf Presiden, 2016). Dwelling time yang dimaksud adalah waktu tunggu atau waktu yang dihitung mulai dari petikemas barang impor dibongkar dari sarana pengangkut hingga barang keluar dari pelabuhan. Jika dibandingkan dengan beberapa negara di Asia, dwelling time di Tanjung Priok masih terlalu tinggi. Dari data yang dikumpulkan dalam rentang bulan Maret sampai dengan September 2014, rata-rata dwelling time di Tanjung Priok mencapai enam hari, di Leam Chabang (Thailand) mencapai lima hari, di Tanjung Lepas (Malaysia) mencapai 3 hari, sedangkan Hongkong dan Singapura telah mencapai dua hari dan kurang dari dua hari.

Hasil kajian dari Direktorat Jenderal Bea dan Cukai Tahun 2016, dwelling time di Tanjung Priok hingga Agustus 2016 masih berlangsung sekitar 4,23 hari. Presiden saat meresmikan Terminal Peti Kemas Kalibaru, 13 September 2016, menegaskan dan mengharapkan agar dwelling time di Pelabuhan Tanjung Priok dapat ditekan hingga 2,5 bahkan 2,2 hari. Jika hal ini dapat diwujudkan maka capaian tersebut dapat menyamai capaian negara tetangga yaitu Singapura yang hingga awal 2016 berada pada 1,5 hari.

Telah diketahui bahwa penyebab dari dwelling time ini adalah lamanya dalam proses pengurusan cleaance dokumen dan lamanya 
pengurusan dokumen bea dan cukai pada Petugas Bea dan Cukai. Disamping juga adanya sewa tempat penumpukan yang cukup mahal, apalagi dengan dikeluarkannya Keputusan Direksi Pelindo tahun 2016, tarif penumpukan peti kemas pada Pelabuhan Tanjung Priok mengalami perubahan yang lebih membebani perusahaan.

Berdasarkan kendala-kendala yang teridentifikasi, dapat diketahui penyebab lamanya proses penerbitan perizinan barang impor. Dari hasil wawancara menunjukkan bahwa terdapat instansi teknis yang masih secara manual memproses pengurusan dan penerbitan izin, yaitu belum adanya sistem informasi berupa aplikasi atau modul yang dibuat untuk melakukan pengajuan permohonan izin impor untuk barang. Dokumen pelengkap yang dibutuhkan oleh instansi teknis, masih juga menjadi salah satu penyebab lamanya pengurusan perizinan untuk dokumen impor barang. Untuk itu JICT kemudian membuat suatu bentuk layanan berupa aplikasi My JICT yang terintegrasi secara baik dan menyeluruh, sehingga pelayanan dapat diakses secara cepat melalui sistem online, kapan saja dan dimanapun customer berada. Dengan adanya aplikasi $M y$ JICT ini menjadi mudah dalam pelayanan penanganan muatan kontainer di Pelabuhan Jakarta khususnya di JICT.

Achmad Lutfi selaku Deputy Operational Manager Ocean Network Express (ONE), sebagai custumer pengguna jasa penanganan muatan kontainer di JICT dengan memanfaatkan aplikasi My JICT menyampaikan beberapa keuntungan dalam penggunaan aplikasi My JICT ini, yaitu :

a. memudahkan proses pembayaran atas jasa kepelabuhanan khususnya untuk pemuatan kontainer,

b. dapat mengatur cash flow sesuai dengan kebutuhan penanganan muatan kontainer,

c. beberapa layanan terminal dapat terintegrasi di dalam satu aplikasi secara sederhana,

d. integrasi dalam sistem untuk meningkatkan penetrasi percepatan dalam pemberian pelayanan antar lembaga, serta mendorong diterapkannya sistem elektronik yang cepat dan efisien di pelabuhan, dan

e. sebagai percontohan dalam pelaksanaan pelayanan elektronik 24 jam di pelabuhan Indonesia.

\section{Persepsi Karyawan JICT Mengenai Penggunaan Aplikasi My JICT dalam Meningkatkan Usaha Terminal Petikemas.}

Program aplikasi My JICT yang telah diluncurkan oleh PT Jakarta International Container Terminal (JICT), sistem pelabuhan 24 jam yang terintegrasi telah dijalankan secara baik sesuai harapan Kementrian Perhubungan (Kemenhub). Dengan layanan ini menjadikan JICT menjadi semakin strategis, sehingga dapat memberikan support terhadap peningkatan perekonomian Indonesia.

Menurut Gunta selaku Presiden Direktur PT. JICT, bahwa integrasi penyatuan sistem pelayanan pelabuhan 24 jam ini dilakukan di beberapa lini pelayanan utama terminal. Peningkatkan penetrasi percepatan layanan antar lembaga, merupakan prinsip dalam integrasi sistem dalam My JICT, dengan mendorong diterapkannya sistem elektronik yang cepat dan efisien di pelabuhan. Dengan keberadaan sistem online ini maka penyedia jasa perantara yang biasa mengurus kapal akan tereliminasi dan para importir dapat mengurus berkasnya secara langsung dari kantornya masing-masing.

Ada tiga klaster layanan dokumen barang dan kapal, yaitu System E-billing untuk pelayanan pembayaran dokumen ekspor impor, sistem Autogate untuk pelayanan truk ekspor impor dan sistem Elektronic Delivery Order (DO Online) untuk integrasi dokumen kapal, yang menjadi layanan utama dalam aplikasi $M y$ JICT yang terintegrasi. Aplikasi My JICT selain tiga layanan utama di atas, juga terdapat pelayanan yaitu melayani transaksi pelayanan petikemas empty dan beberapa transaksi dengan depo-depo petikemas. Penyelesaian dokumen ekspor impor dilakukan secara terintegrasi, cepat dan efisien dengan basis real-time.

Sebagai seorang planner dalam penanganan muatan petikemas di JICT, Dwi Ariyanto menyampaikan bahwa dengan aplikasi My JICT ini kinerja para karyawan JICT menjadi lebih terprogram, fokus dan semakin cepat dan akurat. Banyak kesalahan yang dulu dilakukan karena masih dengan manual sistem, saat ini sudah dapat diminimalkan atau bahkan dihilangkan. Kemudahan yang ditampilkan dalam sistem, baik untuk akses ataupun menginput data menjadikan aplikasi My JICT ini menjadi suatu integrasi sistem yang mendukung kinerja dan pelayanan pengurusan dokumen di pelabuhan lebih optimal. 
Penerapan sistem layanan secara digitalisasi bukan tidak ada kendala atau dampak bagi para karyawan di JICT. Program pelayanan yang sebelumnya dilakukan secara manual dan beralih kepada suatu sistem yang semuanya terintegrasi, mengharuskan JICT untuk memiliki karyawan-karyawan yang memang berkompeten di bidang teknologi dan IT. Hal ini tentunya menjadikan beberapa karyawan yang kurang mahir di bidang IT menjadi kesulitan dalam menjalankan aplikasi My JICT ini. PT JICT dalam hal ini telah memberikan suatu pelatihan dan familiarisasi mengenai aplikasi My JICT ini kepada seluruh karyawan PT JICT. Sehingga kedepannya semua dapat menjalankan sistem ini secara baik dan terpadu.

Dengan adanya sistem aplikasi My JICT ini dapat diyakini bahwa perkembangan JICT ke depannya dalam meningkatkan pelayanan dalam penanganan muatan petikemas akan menjadi semakin maju dan berkembang, sehingga mampu meningkatkan usaha terminal petikemas.

\section{KESIMPULAN}

1. Pelayanan dalam penanganan muatan petikemas menjadi perhatian untuk di tingkatkan, guna menunjang keberhasilan dalam upaya optimalisasi pelayanan ekspor dan impor. Kepastian waktu atau lamanya masa inap barang atau dikenal dengan dwelling time di pelabuhan, serta mahalnya komponen biaya logistik menjadi salah satu kendala dan dinilai telah menyebabkan daya saing logistik Indonesia tertinggal dibanding negara lain. Untuk itu PT JICT kemudian menerapkan layanan aplikasi My JICT, secara sistem belum ada kendala yang yang selama ini dapat menghambat pelayanan. Hanya saja, karena sistem ini merupakan suatu layanan online, yang sangat berpengaruh adalah kondisi network atau layanan jaringan internet dari provider atau penyedia networking.

2. Perubahan dalam pelayanan secara fisik ke pelayanan sistem online di Era 4.0 ini tentunya membawa banyak perubahan besar dalam suatu tatanan birokrasi pelayanan jasa. Sistem aplikasi My JICT, merupakan jawaban dalam mengurangi masa tunggu ataupun dwelling time. Sebagai pelabuhan dengan kegiatan impor yang tinggi, Pelabuhan Tanjung Priok hingga saat ini menjadi sorotan utama dalam hal dwelling time. Aplikasi My JICT memberikan layanan yang terintegrasi secara baik dan menyeluruh, sehingga pelayanan dapat diakses kapan dan dimana saja secara online.

3. Penerapan sistem layanan secara digitalisasi bukan tidak ada kendala atau dampak bagi para karyawan di JICT. Program pelayanan yang sebelumnya dilakukan secara manual dan beralih kepada suatu sistem yang semuanya terintegrasi, mengharuskan JICT untuk memiliki karyawan-karyawan yang memang berkompeten di bidang teknologi dan IT. Hal ini tentunya menjadikan beberapa karyawan yang kurang mahir di bidang IT menjadi kesulitan dalam menjalankan aplikasi My JICT ini.

\section{DAFTAR PUSTAKA}

Abbas Salim, 2012, Manajemen Transportasi, PT RajaGrafindo Persada, Jakarta.

Cholid Narbuko dan Abu Achmadi, 2001, Metodologi Penelitian, Bumi Aksara, Jakarta.

Dayan Hakim, https://www.kompasiana.com/ dokday/589c02dcd77e610e078c3908/ perusahaan-pelayaran container regular liner?page=all, diunduh pada 1/11/2020.

D.A. Lasse, 2014, Manajemen Kepelabuhanan, PT RajaGrafindo Persada, Jakarta.

Dapertemen Pendidikan Nasional, 2015, Kamus Besar Bahasa Indonesia Edisi III, Balai Pustaka, Jakarta.

Direktorat Jenderal Bea dan Cukai, 2016, Hasil Kajian Direktorat Jenderal Bea dan Cukai Tahun 2016, Siaran Pers: Peran DJBC Dalam Menurunkan Dwelling Time di Pelabuhan Tanjung Priok.

Direktur Jenderal Bea dan Cukai. Peraturan Direktur Jenderal Nomor 37 Tahun 2016 tentang Petunjuk Pelaksanaan Pengeluaran Barang Impor Untuk Dipakai.

Elok Widiyati, dan Ridwan, 2014, Kamus Kepelabuhanan dan Pelayaran, Leutika Prio, Yogyakarta.

Engkos Kosasih, dan Hananto Soewedo, 2007, Manajemen Perusahaan Pelayaran, Suatu Pendekatan Praktis dalam Bidang Usaha Pelayaran, Edisi Kedua, (STMT) Trisakti, Jakarta.

Habib Hanafi, dkk., "Pengaruh Persepsi Kemanfaatan dan Persepsi Kemudahan Website UB terhadapSikap Pengguna dengan Pendekatan TAM", Artikel 
diakses pada tanggal 25 Oktober 2019 dari http://administrasibisnis.studentjournal.u b.ac.id.

INSA, 2019, Workshop Мепији 15 Tahun Implementasi Asas Cabotage, di Hotel Grand Mercure, Harmoni, Jakarta, Kamis (07/11/2019), diunggah 11/11/2019, diakses pada $1 / 11 / 2020$.

Kantor Staf Presiden. 13 September 2016. Dwelling Time di Tanjung Priok: dari 7 Hari Menjadi 3,2-3,7 Hari. http://presidenri.go.id/beritaaktual/dwelling-time-di-tanjung-priokdari-7-hari-menjadi-32-37-hari.html

Keputusan Direksi Pelabuhan Indonesia II Nomor HK.56/2/25/P.II-2002.

Lexy J. Moleong, 2006, Metodologi Penelitian Kualitatif, PT. Remaja Rosdakarya, Bandung.

Marimin, 2004, Teknik dan Aplikasi Pengambil Keputusan Kriteria Majemuk, PT.Gramedia Widiasarana Indonesia, Jakarta.

Menteri Republik Indonesia, Peraturan Menteri Keuangan Republik Indonesia Nomor 228 Tahun 2015 tentang Pengeluaran Barang Impor untuk Dipakai.

Negara Republik Indonesia, Undang-Undang Nomor 17 Tahun 2008 tentang Pelayaran.

Peraturan Pemerintah Republik Indonesia Nomor 61 Tahun 2009 tentang Kepelabuhanan.

Peraturan Pemerintah Nomor 64 Tahun 2015 tentang Perubahan Atas Peraturan Pemerintah Nomor 61 Tahun 2009 Tentang Kepelabuhanan.

Peter Salim dan Yenny Salim, 2002, Kamus Bahasa Indonesia Kontemporer, Modern English Perss, Jakarta.

Riant Nugroho, 2003, Kebijakan Publik: Formulasi, implementasi, dan evaluasi, Elex Media Komputindo, Jakarta.

Ridwan Khairandy, 2014, Pokok-Pokok Hukum Dagang, Fakultas Hukum Universitas Islam Indonesia Press, Yogyakarta.

Suyono, 2007, Pengangkut Intermodal Ekspor Impor Melalui Laut, Argya Putra, Jakarta.

Rustian Kamaludin, 2003, Ekonomi Transportasi Karakteristik, Teori, dan Kebijakan, Ghalia Indonesia, , Jakarta.

Sugiyono, 2009, Metode Penelitian Kualitatif Kuantitatif dan R\&D, Alfabeta, Bandung. Sugiyono, 2013, Metode Penelitian Kuantitatif Kualitatif dan $R \& D$, Alfabeta, Bandung.
Sukandarrumidi, 2006, Metodologi Penelitian Petunjuk Praktis Untuk Penelitian Pemula, Cetakan ke-3, Gadjah Mada University Press, Yogyakarta.

Undang-Undang Republik Indonesia Nomor 17 Tahun 2008 tentang Pelayaran.

Menteri Republik Indonesia, Peraturan Menteri Perhubungan Republik Indonesia Indonesia, Peraturan Pemerintah Nomor 61 Tahun 2009 tentang Kepelabuhan.

Menteri Republik Indonesia, Peraturan Menteri Keuangan Republik Indonesia Nomor 228 Tahun 2015 tentang Pengeluaran Barang Impor untuk Dipakai.

Direktur Jenderal Bea dan Cukai. Peraturan Direktur Jenderal Nomor 37 Tahun 2016 tentang Petunjuk Pelaksanaan Pengeluaran Barang Impor Untuk Dipakai. 